\title{
Nutritional quality of milk curd by adding avocado extract (Persea americana, mill) using gombong bamboo (Gigantochloa verticilata)
}

\author{
P T Pandiangan, T H Wahyuni, Hamdan \\ Animal Husbandry Study Program, Faculty of Agriculture, \\ University of North Sumatra, Medan 20155, Indonesia \\ E-mail:trihestiwahyuni@yahoo.com
}

\begin{abstract}
Curd is a traditional fermented buffalo milk from West Sumatra. Fermentation in curd making occurs spontaneously, meaning that fermentation occurs naturally without the addition of a starter. This study aims to determine the nutritional content of cow milk curd with the addition of avocado extract (Persea americana, Mill) various levels using Gombong bamboo (Gigantochloa verticilata).

This research was conducted at the Analogy and Physiology Laboratory of the Faculty of Agriculture, University of North Sumatra in November 2018December 2018. The design used in this study was a completely randomized design (CRD) with 5 treatments and 4 replications. The parameters analyzed were Protein, Fat, and $\mathrm{pH}$. The results showed that cow milk curd with the addition of avocado (Persea americana, Mill) extract various levels using Gombong bamboo (Gigantochloa verticilata) significantly had different effects on the nutritional value of protein, fat and $\mathrm{pH}$. From the nutritional value studied, the highest protein: P1 $7.57 \%$ with the addition of avocado fruit extract (Persea americana, Mill) 6\%, fat average: P1 $7.08 \%$ with the addition of avocado fruit extract (Persea americana, Mill) $6 \%, \mathrm{pH}: \mathrm{P} 45.30 \%$ with the addition of avocado fruit extract (Persea americana, Mill) 24\%.
\end{abstract}

\section{Introduction}

Curd is a traditional fermented milk product with raw materials for buffalo milk from West Sumatra. Fermentation in curd making occurs spontaneously, meaning that fermentation occurs naturally without the addition of a starter. The buffalo milk produced directly put into a bamboo tube that has been left alone for one night, then covered with banana leaves. In general, the bamboo tube is stored at room temperature for 1-2 nights until curd is formed [1].

The use of buffalo milk as a raw material needs to be considered considering that buffalo milk production in the curd production area continues to decline as the buffalo population decreases. This condition automatically decreases buffalo milk production [2]. 
Processing of curd from cow's milk with the addition of avocado extract (Persea americana, Mill) is one of the innovations that aims to take advantage of the high production of cow milk and avocado. In addition, also to improve the quality of nutrition and taste in curds [3].

\section{Research Materials and Methods}

2.1 This research was conducted at the Research and Technology Laboratory of the Faculty of Agriculture, University of North Sumatra Jl. A. Sofyan No. 3 Medan, located at an altitude of $25 \mathrm{~m}$ above sea level for 2 months starting from November 2018 to December 2018.

\subsection{Materials and Research Tools}

material

The material used in this study is 9 liters of fresh cow's milk, $2 \mathrm{~kg}$ of avocado fruit, as the research object; fresh gombong bamboo as a place for making curds; Banana leaves as the end cover on bamboo when doing fermentation and chemicals in analyzing protein, fat and $\mathrm{pH}$.

Tool

The tool used is a saw to cut bamboo; blender to smooth the avocado; filter tool, pan, beaker glass, erlenmeyer, stove to heat milk; thermometer to measure the temperature of milk when heated; silk to stir milk when heated; spoon as a maker of curd from bamboo; basin as a place for making curds.

\subsection{Research Methods}

The research method for curd from cow's milk by adding avocado fruit extract (Persea americana, Mill) fermented with gombong bamboo (Gigantochloa verticilata) using a completely randomized design (CRD) with 5 treatments and 4 replications.

\section{Implementation of Research Making curd}

Provide bamboo with a diameter of $\pm 4-5 \mathrm{~cm}$ and cut $\pm 25 \mathrm{~cm}$. Then 9 liters of cow's milk is heated for 10 minutes at $40^{\circ} \mathrm{C}$ then cooled and the avocado fruit has been blended as much as $2 \mathrm{~kg}$. After cow's milk is cooled then $470 \mathrm{ml}, 440 \mathrm{ml}, 410 \mathrm{ml}$, and $380 \mathrm{ml}$ of cow's milk are put into the container and mixed with avocado extract $6 \%, 12 \%, 18 \%$ and $24 \%$ then put into each bamboo. Then the bamboo is covered with banana leaves, which are then fermented and then fermented for 3 days at room temperature.

\section{Research Parameters \\ Protein Level Test}

Protein testing uses the Kjedahl method

\section{Test of fat content}

Fat testing using the soxlet method is taken from the squash, dried in an oven and then put into the desiccator and then weighed. 


\section{PH test}

$\mathrm{PH}$ measurement using a standardized $\mathrm{pH}$ instrument or calibrated with a buffer solution $\mathrm{pH}$ (4.00) and buffer $\mathrm{pH}$ (7.00) before use.

\section{Data analysis}

The data obtained were analyzed using a completely randomized design (CRD), if the treatment was significantly different $(\mathrm{P}=0.05)$ or very significantly different $(\mathrm{P}<0.01)$ followed by the Duncan test.

\section{Results and Discussion}

3.1.1 Levels of Cow Curd Protein with the addition of Avocado fruit extract (Persea americana, Mill)

Table 1. Protein levels with the addition of avocado extracts of various levels using gombong bamboo.

\begin{tabular}{ccccccc}
\hline Treatments & 1 & 2 & 3 & 4 & Total & Average \\
\hline P0 & 6,65 & 6,78 & 7,05 & 7,29 & 27,77 & $6,94^{\mathrm{a}}$ \\
P1 & 7,74 & 7,37 & 7,57 & 7,60 & 30,28 & $7,57^{\mathrm{b}}$ \\
P2 & 7,35 & 6,43 & 7,31 & 6,50 & 27,59 & $6,90^{\mathrm{a}}$ \\
P3 & 6,53 & 6,07 & 7,13 & 6,38 & 26,11 & $6,53^{\mathrm{a}}$ \\
P4 & 6,36 & 6,81 & 6,44 & 6,61 & 26,22 & $6,56^{\mathrm{a}}$ \\
\hline
\end{tabular}

Description: Different superscriptions in the same row or column indicate presence significant difference in the Duncan test $(\mathrm{P}<0.05)$

The results of the variance analysis showed that the protein content of curd sap with the addition of avocado extract (Persea americana, Mill) of various levels using bamboo gombong was significantly different $(\mathrm{P}<0.05)$. This happens because during the fermentation process, the bacteria found in gombong bamboo will overhaul the avocado (Persea americana, Mill) extract protein and lactose in cow's milk into lactic acid in an acidic atmosphere which will cause the curd protein to clot. This is in accordance with the statement of Poedjiadi (2007) which states that proteins will experience denaturation (clumping) during the fermentation process by microbes and these microbes have a growth phase. This is supported by Rahayu and Ardhi (2010) which states that microorganisms have phases in growth, namely adaptation phase, logarithmic phase, slow growth phase and death phase. In the logarithmic phase the fermentation process works very well but in the slow growth phase the fermentation runs less optimally because the food supply starts to decrease.

\subsubsection{Cow Curd Fat Content with the addition of Avocado fruit extract (Persea americana, Mill)}

Table 2. Levels of fat with the addition of avocado extracts of various levels using gombong bamboo.

\begin{tabular}{ccccccc}
\hline Treatments & 1 & 2 & 3 & 4 & Total & Average \\
\hline P0 & 6,36 & 6,42 & 6,95 & 7,00 & 26,73 & $6,68^{\mathrm{bc}}$ \\
P1 & 7,11 & 7,17 & 6,97 & 7,07 & 28,32 & $7,08^{\mathrm{c}}$ \\
P2 & 7,06 & 7,06 & 7,15 & 6,37 & 27,64 & $6,91^{\mathrm{c}}$ \\
\hline
\end{tabular}




\begin{tabular}{lcccccc}
\hline P3 & 6,58 & 6,08 & 6,81 & 6,37 & 25,84 & $6,46^{\mathrm{b}}$ \\
P4 & 5,57 & 5,3 & 5,97 & 6,04 & 22,88 & $5,72^{\mathrm{a}}$ \\
\hline
\end{tabular}

Description: Different superscriptions in the same row or column indicate presence significant difference in the Duncan test $(\mathrm{P}<0.05)$

The results of the variance analysis showed that the fat content of beef cattle with the addition of avocado extract (Persea americana, Mill) of various levels using bamboo gombong had significant effect $(\mathrm{P}<0.05)$. High curd fat levels are caused by the activity of a number of lactic acid bacteria (LAB) in avocado and milk extracts fermented using gombong bamboo so that they can convert fat into fatty acids and glycerol. This is in accordance with Wahyuni's statement (2009) which states that curd fat levels can increase due to the activity of a number of bacteria in bamboo, lactic acid bacteria, Lactobacillus sp, so that the fat content in curds will increase because these bacteria can form fatty acids and glycerol. This is supported by Winarno (1993) who states that the more fatty acids that can be broken down by LAB (lactic acid bacteria), the higher the fat content. The fat content in the curd will increase but the curd is not dangerous when consumed by people with hypercholesterolemia.

\subsection{3 pH of Cow Curd with the addition of Avocado fruit extract (Persea americana, Mill)}

Table 3. $\mathrm{pH}$ acidity test with the addition of avocado extracts of various levels.

\begin{tabular}{ccccccc}
\hline Treatments & 1 & 2 & 3 & 4 & Total & Average \\
\hline P0 & 4,20 & 4,09 & 4,60 & 3,90 & 16,79 & $4,20^{\mathrm{a}}$ \\
P1 & 3,27 & 3,89 & 4,50 & 4,00 & 15,66 & $3,92^{\mathrm{a}}$ \\
P2 & 3,77 & 3,94 & 5,44 & 4,32 & 17,47 & $4,37^{\mathrm{a}}$ \\
P3 & 3,00 & 3,20 & 4,00 & 4,01 & 14,21 & $3,55^{\mathrm{a}}$ \\
P4 & 5,67 & 5,80 & 5,01 & 4,70 & 21,18 & $5,30^{\mathrm{b}}$ \\
\hline
\end{tabular}

Description: Different superscriptions in the same row or column indicate presence significant difference in the Duncan test $(\mathrm{P}<0.05)$

The results of the variance analysis showed that pHdadih sap with the addition of avocado fruit extract (Persea americana, Mill) of various levels using significantly different gombong bamboo $(\mathrm{P}<0.05)$. The presence of bacterial activity in avocado fruit extract and cow's milk in the fermentation process in bamboo which can remodel lactose into lactic acid so that the curd becomes acidic. This is in accordance with the statement of Anugrah (2005) which states that the acidity of curds in addition to depending on protein content is also influenced by the activity of bacteria that remodel lactose to lactic acid so that it becomes acidic. The more number of bacteria that overhaul lactose into lactic acid will cause a decrease in curd pH. This is also supported by Rahayu and Ardhi (2010) who state that microorganisms have phases in growth, namely adaptation phase, logarithmic phase, slow growth phase and death phase. In the logarithmic phase the fermentation process works very well but in the slow growth phase the fermentation runs less optimally because the food supply starts to decrease. 


\subsubsection{Recapitulation of Research Results}

Table 4. Recapitulation of the results of the nutritional test of cow milk curd avocado extract (Persea americana, Mill) various levels using gombong bamboo

(Gigantochloa verticilata)

\begin{tabular}{llcl}
\hline Treatments & Protein content & $\begin{array}{c}\text { Average } \\
\text { fat level }\end{array}$ & $\mathrm{pH}$ \\
\hline P0 & $6,94^{\mathrm{a}}$ & $6,68^{\mathrm{oc}}$ & $4,20^{\mathrm{a}}$ \\
P1 & $7,57^{\mathrm{D}}$ & $7,08^{\mathrm{c}}$ & $3,92^{\mathrm{a}}$ \\
P2 & $6,90^{\mathrm{a}}$ & $6,91^{\mathrm{c}}$ & $4,37^{\mathrm{a}}$ \\
P3 & $6,53^{\mathrm{a}}$ & $6,46^{\mathrm{D}}$ & $3,55^{\mathrm{a}}$ \\
P4 & $6,56^{\mathrm{a}}$ & $5,72^{\mathrm{a}}$ & $5,30^{\mathrm{b}}$ \\
\hline
\end{tabular}

In table 4 we can see that the research parameters, which are protein content, fat content and better $\mathrm{pH}$ are found in $\mathrm{P} 1$ with the addition of $6 \%$ avocado extract. This is due to the addition of avocado extract in the processing of curd so that it will increase its nutritional content. This is in accordance with the statement of Alase (1994) which states that bamboo segments contain a number of microbes consisting of molds, yeasts, microorganisms forming lactic acid protein, and spore forming.

\section{Conclusion}

From the nutritional analysis of protein, fat, and $\mathrm{pH}$, it was found that the best curd processing was found in cow milk curd with the addition of avocado extract (Persea americana, Mill) using 6\% gombong bamboo (Gigantochloa verticilata).

\section{References}

[1] Anugrah, F. 2005. "Analisis Faktor-Faktor Yang Mempengaruhi Konversi Lahan Sawah ke Penggunaan Non Pertanian di Kabupaten Tangerang”. Skripsi. Bogor. Institut Pertanian Bogor

[2] Alase,C.A. 1994. Pengaruh Jenis Kemasan dan Suhu Penyimpananterhadap Kualitas dan Daya Simpan Dadih Susu Sapi yangDipasteurisasi. Skripsi. Fakultas Teknologi Pertanian, InstitutPertanian Bogor, Bogor.

[3] Poedjiadi, Anna. 2007. Dasar-dasar Biokimia. Jakarta: UI-Press. Sugiyono (1992)

[4] Rahayu, Triastuti dan Ardhi, Waskito. 2010. Modul Praktikum Mikrobiologi. Surakarta: UMS.

[5] Wahyuni Sri. 2009. Uji Kadar Protein dan Lemak pada Keju Kedelai dengan Perbandingan Inokulum Lactobacillus Bulgaricus dan Streptococcus Lactis yang Berbeda. Naskah publikasi. Program Studi Pendidikan Biologi, Fakultas Keguruan dan Ilmu Pendidikan Biologi. Surakarta: Universitas Muhammadiyah Surakarta

[6] Winarno, F.G. 2002. Kimia Pangan dan Gizi.PT. Gramedia Pustaka Utama 